\title{
Features and outcomes of lupus nephritis in Morocco: analysis of II 4 patients
}

This article was published in the following Dove Press journal: International Journal of Nephrology and Renovascular Disease 21 November 2013

Number of times this article has been viewed

\author{
Intissar Haddiya' \\ Hakim Hamzaoui' \\ Nabil Tachfouti ${ }^{2}$ \\ Zitouna Al Hamany ${ }^{3}$ \\ Aicha Radoui' \\ Najoua Zbiti' \\ Yamama Amar' \\ Hakima Rhou' \\ Loubna Benamar' \\ Naima Ouzeddoun' \\ Rabea Bayahia' \\ 'Department of Nephrology, Dialysis, \\ and Renal Transplantation, Ibn Sina \\ University Hospital, Rabat, Morocco; \\ ${ }^{2}$ Department of Epidemiology, Fez, \\ Morocco; ${ }^{3}$ Department of Pathology, \\ Rabat Children's Hospital, Rabat, \\ Morocco
}

Background: There is wide variation in clinical presentation and outcome of lupus nephritis (LN) among different ethnic groups. Few data for LN exist on North Africans, especially those from Morocco. The aim of our study was to review retrospectively the features and outcome of LN in Moroccan patients.

Patients and methods: We performed a single-center retrospective study. A total of 114 patients with LN were included. All patients met American Rheumatism Association criteria. LN was classified according to the International Society of Nephrology/Renal Pathology Society classification. We adopted previously defined outcome criteria for LN.

Results: There were 101 females and 13 males, with a mean age of 29.9 years. At first presentation, we noted hypertension in $33 \%$, hematuria in $76 \%$, nephrotic syndrome in $53 \%$, and renal failure in $60 \%$ of cases. Renal biopsy revealed predominant proliferative classes in more than $80 \%$ of patients. Patients received different regimens mainly based on intravenous cyclophosphamide. After a mean follow-up of 22 months, remission occurred in $45.5 \%$, relapses in $82 \%$, end-stage renal failure in $21 \%$, and death in $16 \%$ of cases. Infection and neurological and cardiovascular diseases were the most frequent causes of death.

Conclusion: $\mathrm{LN}$ seems to be severe in our study, with a predominance of proliferative forms, severe renal manifestations, and poor renal and overall survival.

Keywords: lupus nephritis, systemic lupus erythematosus, nephritis

\section{Introduction}

Nephritis is one of the most severe complications of systematic lupus erythematosus (SLE). ${ }^{1}$ Up to $60 \%$ of adults and $80 \%$ of children with SLE develop lupus nephritis (LN). ${ }^{2}$ The clinical presentation of kidney involvement is highly variable, ranging from mild asymptomatic proteinuria to rapidly progressive glomerulonephritis. Biological features generally include varying degrees of glomerular involvement with proteinuria that is nephrotic in up to $65 \%$ of cases, as well as hematuria with red-cell casts and/or acute renal failure. ${ }^{1}$ Diffuse proliferative LN is the most common histological variant. Furthermore, it has the worst prognosis, with a reported $17 \%$ 5-year survival without treatment. ${ }^{3}$ Progress in immunosuppressive therapy has improved renal and global survival. Five-year patient survival was approximately $55 \%$ in 1970 versus up to $80 \%$ a decade later, ${ }^{4}$ and currently the 5-year survival rate reaches about $90 \%{ }^{3}$ Prognostic factors of renal involvement include demographic (age, sex, race), genetic and immunological features (anti double-stranded DNA [dsDNA], anti-C1q, antiphospholipid antibodies), histopathological findings, clinical and laboratory signs (high serum creatinine, nephrotic syndrome, hypertension), and are affected also by treatment regimens and patient compliance. ${ }^{5}$
Correspondence: Intissar Haddiya

7 Bloc E, Secteur 2I, Rue Assoufairaa, Hay Riad, Rabat, Morocco

Tel +2I2 66I 28I 400

Fax +212536500609

Email intissarhaddiya@hotmail.com 
In Morocco, no data describing LN have been published previously. In order to make a clear picture, we reviewed retrospectively 114 cases of $\mathrm{LN}$ followed in our unit between 2001 and 2010. The aim of our study was to analyze the clinical and histological features of patients with LN and to evaluate the outcome of $\mathrm{LN}$ with special regards to proliferative and membranous forms.

\section{Subjects and methods}

Between January 2001 and December 2010, 114 cases of LN were diagnosed, treated, and followed up by the Department of Nephrology, Dialysis, and Renal Transplantation, Ibn Sina University Hospital, Rabat, Morocco. All patients included in this single-center retrospective analysis fulfilled at least four of the revised American Rheumatism Association criteria for SLE. ${ }^{6}$ LN was defined as positive proteinuria (persistent proteinuria of greater than $0.5 \mathrm{~g}$ per day) and/or active urinary sediment (hematuria) and/or presence of renal failure (increase in serum creatinine of more than $1.5 \mathrm{mg} / \mathrm{dL}$ ). Renal biopsies were performed in 96 patients. Eighteen did not have biopsy, mainly because of death or contraindications. Histological findings were classified according to the International Society of Nephrology/Renal Pathology Society 2003 classification of lupus nephritis. ${ }^{7}$ All biopsies performed before 2004 were reviewed by our pathologist and reclassified according to the new classification.

Analyzed parameters included: (1) demographic data - age, sex; (2) clinical signs - blood pressure and American Rheumatism Association criteria; (3) biological parameters - serum creatinine, urinalysis (proteinuria and hematuria), antibodies against dsDNA, antiphospholipid antibody (lupus anticoagulant, anticardiolipin antibody), complement components C3 and C4; (4) immunosuppressive therapy; and (5) outcomes - remission, relapse, end-stage renal disease (ESRD), and death.

ESRD was defined as a need for chronic dialysis or kidney transplantation. Hypertension was defined as blood pressure superior to $140 / 90 \mathrm{mmHg}$ or the use of any antihypertensive medications. We adopted outcome criteria for LN as defined by Boumpas: ${ }^{8}$

- Complete remission was defined as stabilization or improvement in renal function, resolution of urinesediment abnormalities (absence of hematuria or cellular cast), proteinuria $<1 \mathrm{~g}$ /day and normalization of complement $\mathrm{C} 3$ for at least 6 months.

- Partial remission was defined as stabilization or improvement in renal function, decrease of more than
$50 \%$ in hematuria and significant change in proteinuria ( $\geq 50 \%$ decrease if baseline nephrotic syndrome, but to less than $3 \mathrm{~g} /$ day, $\leq 1 \mathrm{~g}$ /day if baseline nonnephrotic) for at least 6 months.

- Relapse was defined as increase in 24-hour proteinuria $>2 \mathrm{~g} /$ day or doubling if $>3.5 \mathrm{~g} /$ day after response and/or activity increase in urine sediment and/or increase in serum creatinine. All relapses were documented by a renal biopsy.

The therapeutic protocol that we used in our patients was as follows. All patients with proliferative classes as well as class V LN received a 3-day pulse of methylprednisolone, followed by oral prednisone ( $1 \mathrm{mg} / \mathrm{kg}$ /day). Prednisone was tapered progressively in order to reach $10 \mathrm{mg} /$ day 6 months after the beginning of the treatment. Immunosuppressive treatment consisted of six monthly pulses of intravenous (IV) cyclophosphamide (CYC; 500-1000 mg/month) as induction of renal remission. Maintenance therapy consisted of six trimonthly pulses of IV CYC or oral mycophenolate mofetil (MMF; 2-3 g/day) or oral azathioprine (AZA) $100 \mathrm{mg}$ /day for 2 years, as well as oral corticosteroid (CS) therapy. Oral steroid therapy was never stopped during follow-up. Thus, our patients remained at a steroid dosage of 5-10 mg daily.

Follow up procedures in our unit were as follows. During induction treatment, the patients were seen monthly with a physical and biological assessment prior to CYC pulse. During and after maintenance treatment, patients were seen each trimester. They underwent a physical examination as well as biological tests. Patients presenting with a complication during follow-up were managed in the emergency room of our unit.

The statistical package SPSS 17.0 (IBM, Armonk, NY, USA) was used to analyze sample data. Means \pm standard deviations were used for descriptive analysis. Survival curves were drawn using the Kaplan-Meier estimate. Univariate analysis was used to investigate the prognostic value of continuous and binary variables.

\section{Results}

Patients were $29.89 \pm 9.8(10-65)$ years of age at first presentation. There were 101 females $(88.6 \%)$ and 13 males (11.4\%), making a sex ratio of 7.76:1. Initial presentation of SLE in the present work was mostly with joint and skin manifestations in $85 \%$ and $74 \%$, respectively. Time between diagnosis of SLE and the onset of renal disease was $9.7 \pm 3.6$ months. At admission, $75.4 \%$ of the patients 
presented with LN at the diagnosis of lupus. Also, all the reported initial LN flares in this study were the first ones that occurred in our patients.

Moreover, at presentation, 38 (33.3\%) of our patients had hypertension. Hematuria was seen in $87(76.3 \%)$ patients. Nephrotic syndrome was found in 60 patients $(52.6 \%)$ and renal failure in 68 patients (59.6\%). Seventeen (14.9\%) patients required acute renal replacement therapy. Low components of complement $\mathrm{C} 3$ and $\mathrm{C} 4$ were seen in $71.9 \%$ and $65.5 \%$, respectively. Anti-dsDNA antibody was present in $65.7 \%$ of patients. Other clinical signs are summarized in Table 1.

Of 96 patients in whom renal biopsy was performed, three (3.1\%) had LN class I, two (2\%) class II, ten (10.4\%) class III, sixty (62.5\%) class IV, eight (8.3\%) class V, and three (3.1\%) class VI. Ten (10.4\%) patients had combined classes (eight patients had class $\mathrm{V}$ combined with class IV, and two others had class V combined with class III). It is important to note that all proliferative LN classes showed signs of activity in our series.

Mean follow-up was $22.63 \pm 19.47$ (6-72) months. Two patients were lost to view before initial immunosuppressive therapy; therefore, they were not included in further analysis. Remissions occurred in 51 (45.53\%) patients. Forty-two of them $(82.35 \%)$ relapsed at least once (Figure 1).
At 6 months, $66 \%$ of our patients achieved remission (Figure 2). Of all patients, $24(21.42 \%)$ progressed to ESRD, and 18 (16.07\%) died because of infectious complications in ten patients, severe neurologic state in four and acute cardiovascular events in four patients (Table 2).

\section{Subgroup analysis of patients with active proliferative LN classes}

Proliferative classes were present in $80(70.17 \%)$ patients. Class III occurred in ten patients, class IV in 60 patients, and combined classes in ten (10.4\%) patients. Seventy patients were female and ten were male. Mean age was $31.1 \pm 8.55$ (16-52) years. Nephrotic syndrome was present in 61 (76.2\%) patients, active urinary sediment in $63(78.7 \%)$, renal failure in $55(68.7 \%)$ with mean serum creatinine of $4.46 \mathrm{mg} / \mathrm{dL}$, and hypertension in 35 (43.7\%).

All patients with proliferative classes received a 3-day pulse of methylprednisolone followed by oral prednisone ( $1 \mathrm{mg} / \mathrm{kg} /$ day) and six monthly pulses of IV CYC (500-1000 $\mathrm{mg} / \mathrm{month})$ as induction of renal remission. Maintenance therapy was six trimonthly pulses of IV CYC in 55 patients $(68.75 \%), 2$ years of $100 \mathrm{mg} /$ day AZA in 17 patients $(21.25 \%)$ or $2 \mathrm{~g} /$ day of MMF in two patients $(2,5 \%)$, as well as CS therapy.

Table I Characteristics of patients with lupus nephritis

\begin{tabular}{|c|c|c|c|c|c|c|c|c|c|}
\hline & All patients & & & & & & & Combined & Not done \\
\hline Classes of lupus nephritis & & I & II & III & IV & $\mathbf{V}$ & VI & & \\
\hline Number & 114 & 3 & 2 & 10 & 60 & 8 & 3 & 10 & 18 \\
\hline Age (years) & 29.8 & 34.3 & 30 & 32.9 & 28.8 & 28.1 & 34.3 & 31.6 & 30.6 \\
\hline Male & 13 & 0 & 0 & I & 7 & 0 & $\mathrm{I}$ & 2 & 2 \\
\hline Female & 101 & 3 & 2 & 9 & 53 & 8 & 2 & 8 & 16 \\
\hline Hypertension (\%) & 33.3 & 0 & 50 & 25 & 30 & 12.5 & 66.6 & 50 & 66.6 \\
\hline Renal failure (\%) & 59.6 & 0 & 0 & 40 & 78.3 & 37.5 & 100 & 40 & 38.9 \\
\hline Serum creatinine $(\mathrm{mg} / \mathrm{dL})$ & 2.36 & 0.8 & 0.55 & 4.84 & 4.63 & 1.68 & 5.8 & 3.91 & 2.98 \\
\hline Proteinuria (g/day) & 3.5 & 3.23 & 1.6 & 2.3 & 4.1 & 3.8 & I.I & 4.1 & $\mathrm{I} .75$ \\
\hline Nephrotic syndrome (\%) & 52.6 & 66.6 & 50 & 75 & 81.4 & 75 & 0 & 70 & 50 \\
\hline Hematuria (\%) & 76.3 & 33.3 & 50 & 70 & 83.3 & 37.5 & 66.6 & 70 & 50 \\
\hline Skin involvement (\%) & 74.5 & 66.6 & 100 & 90 & 63.3 & 62.5 & 100 & 70 & 88.9 \\
\hline Arthralgia (\%) & 85 & 66.6 & 100 & 100 & 86.7 & 62.5 & 100 & 70 & 88.9 \\
\hline Arthritis (\%) & 16.6 & 0 & 0 & 30 & 15 & 25 & 33.3 & 10 & 22.2 \\
\hline CNS involvement (\%) & 13.5 & 0 & 50 & 40 & 13.4 & 12.5 & 0 & 20 & II.I \\
\hline Serositis (\%) & 12.2 & 0 & 50 & 20 & 10 & 25 & 0 & 0 & II.I \\
\hline Leukopenia (\%) & 25.4 & 33.3 & 50 & 40 & 23.7 & 37.5 & 33.3 & 20 & 16.7 \\
\hline Anemia (\%) & 91.2 & 66.6 & 100 & 100 & 91.7 & 87.5 & 100 & 90 & 88.9 \\
\hline Thrombocytopenia (\%) & 19.2 & 0 & 100 & 10 & 15.3 & 25 & 0 & 0 & 50 \\
\hline Low C3 (\%) & 71.9 & 66.6 & 50 & 80 & 76.7 & 62.5 & 66.6 & 90 & 61.1 \\
\hline Low C4 (\%) & 67.5 & 33.3 & 50 & 70 & 73.3 & 62.5 & 66.6 & 90 & 44.4 \\
\hline Anti-dsDNA (\%) & 67.5 & 66.6 & 100 & 70 & 81.7 & 25 & 100 & 50 & 72.2 \\
\hline Antiphospholipids (\%) & 67.9 & 33.3 & 50 & 30 & 62.6 & 37.5 & 66.6 & 50 & 16.7 \\
\hline
\end{tabular}

Abbreviations: CNS, central nervous system; dsDNA, double-stranded DNA. 


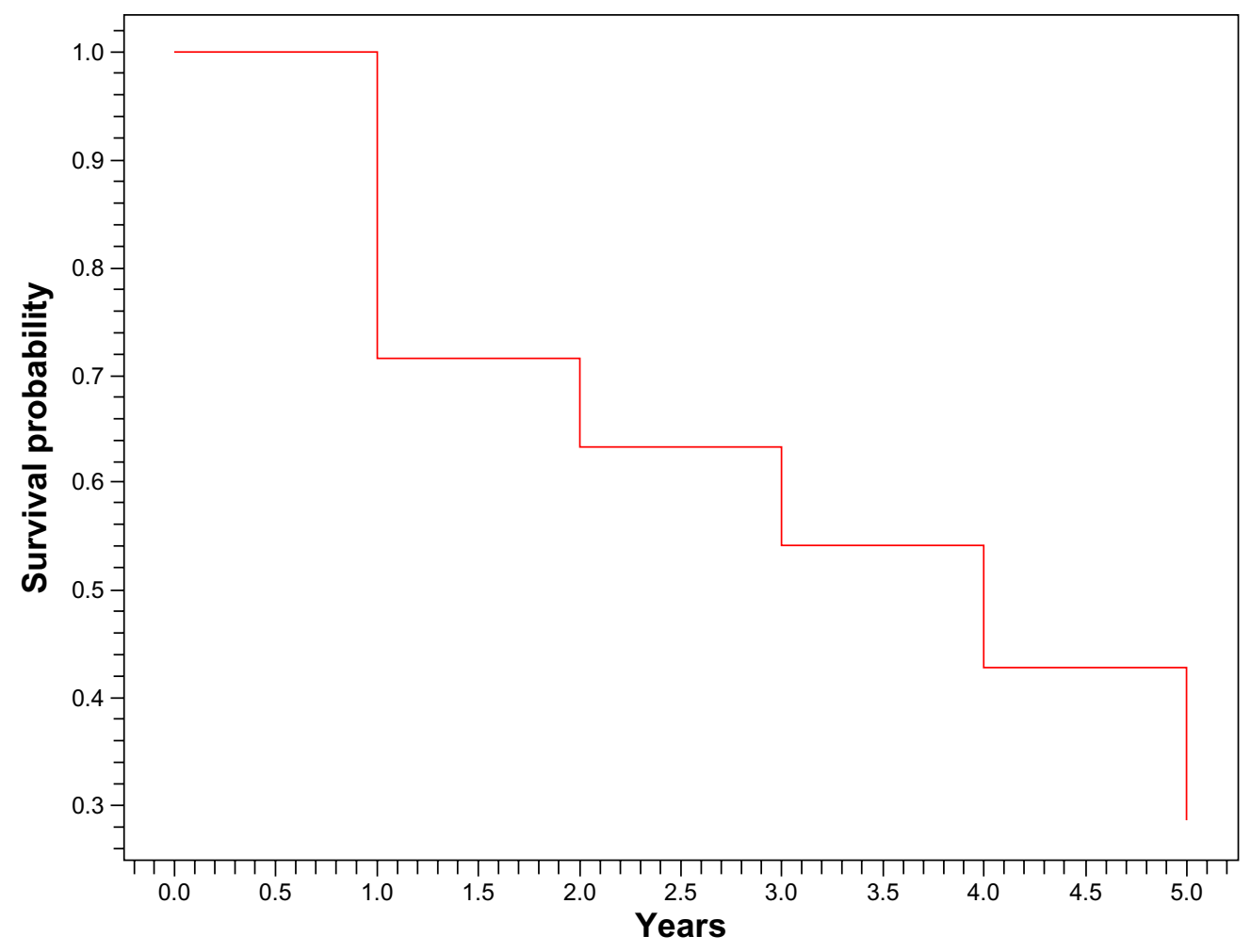

Figure I Kaplan-Meier survival curve (time to relapse).

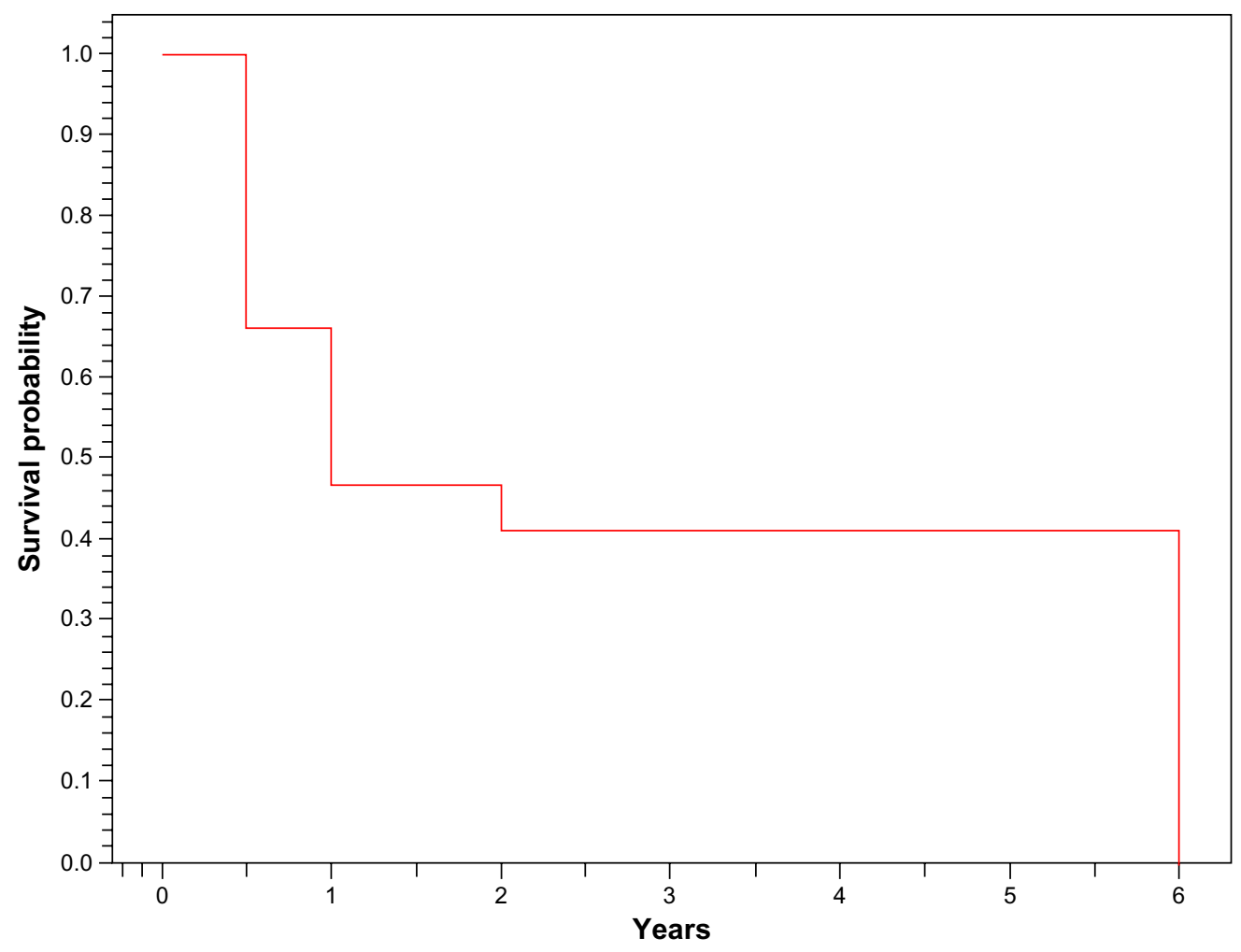

Figure 2 Kaplan-Meier survival curve (time to remission). 
Table 2 Analysis of patients based on treatment and outcomes

\begin{tabular}{|c|c|c|c|c|c|c|c|c|c|c|}
\hline \multirow{2}{*}{\multicolumn{2}{|c|}{$\begin{array}{l}\text { All pat } \\
\text { Classes of lupus nephritis }\end{array}$}} & \multirow{3}{*}{$\begin{array}{l}1 \\
3\end{array}$} & \multirow{3}{*}{$\begin{array}{l}\text { II } \\
2\end{array}$} & \multirow{3}{*}{$\begin{array}{l}\text { III } \\
10\end{array}$} & \multirow{3}{*}{$\begin{array}{l}\text { IV } \\
60\end{array}$} & \multirow{3}{*}{$\begin{array}{l}\mathbf{V} \\
8\end{array}$} & \multirow{3}{*}{$\begin{array}{l}\text { VI } \\
3\end{array}$} & \multirow{3}{*}{$\begin{array}{l}\text { III + V } \\
3\end{array}$} & \multirow{3}{*}{$\begin{array}{l}\text { IV + V } \\
8\end{array}$} & \multirow{3}{*}{$\begin{array}{l}\text { Not done } \\
18\end{array}$} \\
\hline & & & & & & & & & & \\
\hline Number & 114 & & & & & & & & & \\
\hline \multicolumn{11}{|l|}{ Treatment } \\
\hline$M P+O C$ & 109 & 2 & 2 & 10 & 60 & 7 & 3 & 2 & 7 & 16 \\
\hline CYC (IV) & 66 & 0 & 0 & 7 & 44 & 4 & 1 & 1 & 5 & 4 \\
\hline \multicolumn{11}{|l|}{ Maintenance } \\
\hline CYC (IV) & 66 & 0 & 0 & 7 & 44 & 4 & I & I & 5 & 4 \\
\hline$A Z A$ & 21 & 0 & 0 & 3 & 14 & 1 & 0 & 1 & 0 & 2 \\
\hline MMF & 2 & 0 & 0 & 0 & 2 & 0 & 0 & 0 & 0 & 0 \\
\hline \multicolumn{11}{|l|}{ Remission } \\
\hline Yes & 51 & 2 & I & 4 & 25 & 4 & I & I & 3 & 10 \\
\hline Partial & 28 & 0 & I & I & 19 & 2 & 1 & 0 & 2 & 2 \\
\hline Complete & 23 & 2 & 0 & 3 & 6 & 2 & 0 & I & I & 8 \\
\hline No & 61 & 0 & I & 6 & 35 & 4 & 2 & I & 5 & 7 \\
\hline Relapses & 42 & 0 & 0 & 4 & 22 & 3 & 1 & I & 5 & 6 \\
\hline ESRD & 24 & 0 & I & 4 & 14 & 1 & 1 & 0 & I & 2 \\
\hline Death & 18 & 0 & I & I & 9 & I & I & 0 & I & 4 \\
\hline
\end{tabular}

Abbreviations: MP, methylprednisolone; OC, oral corticosteroids; CYC, cyclophosphamide; IV, intravenous; AZA, azathioprine; MMF, mycophenolate mofetil; ESRD, end-stage renal disease.

Remission was noted in $32(40 \%)$ patients. Complete and partial remission were observed in 21 patients $(26.25 \%)$ and eleven patients $(13.75 \%)$, respectively. Forty-seven of our LN active proliferative class patients (58.75\%) relapsed. At the end of the follow-up, the total number of patients who progressed to ESRD was 19 (23.75\%). During the follow-up, $11(13.75 \%)$ patients died.

\section{Subgroup analysis of patients with class $V$ disease stage}

Eight (7\%) patients with mean age of $28.1 \pm 10$ (14-43) years had membranous LN. At the time of biopsy, six (75\%) of them had nephrotic syndrome with mean proteinuria of $3.8 \pm 2.24 \mathrm{~g}$ /day. Only three $(37.5 \%)$ had hematuria, while hypertension was seen in one (12.5\%) patient. Renal failure was present in three $(37.5 \%)$ patients, with mean serum creatinine of $1.68 \pm 1.35 \mathrm{mg} / \mathrm{dL}$. Another feature of class $\mathrm{V}$ was a high frequency of negative anti-dsDNA antibodies (75\%). For induction of renal remission, all patients except one received pulses of methylprednisolone followed by oral prednisone at $1 \mathrm{mg} / \mathrm{kg} /$ day on a regressive regimen. Four patients had six monthly pulses of IV CYC (500-1000 mg/month). As maintenance therapy, three of them had six trimonthly pulses of IV CYC and one patient had AZA $100 \mathrm{mg} /$ day.

Four patients (50\%) had remission. Relapse occurred in three. At the end of the follow-up, one patient developed ESRD and another died because of a neurologic complication.
In our study, $3 \%$ of our patients developed ESRD at 1 year and $15 \%$ at 5 years. Global survival was $84.5 \%$ at 1 year and $76 \%$ at 5 years (Figures 3 and 4). Among the clinical features at presentation that were associated with occurrence of ESRD or death were short mean time between SLE and LN $(P=0.04)$, renal failure at admission $(P=0.01)$, and anemia $(P=0.03)$ (Table 3).

Regarding our patients' treatment, induction therapy was based on CYC in all cases. For maintenance treatment, most of our patients received trimonthly pulses of CYC, while AZA and MMF were used in $13.75 \%$ and $25 \%$, respectively. Also, maintenance treatment duration did not exceed 2 years in any cases. Moreover, antimalarial drugs were used in only $8.7 \%$ of patients.

\section{Discussion}

This is the first published study describing LN in Morocco. It was performed on a cohort of 114 patients followed up in a single center. The Moroccan population has arisen from a great intermingling of different populations throughout history, mainly composed of Caucasians (Berbers and Arabs) and black Africans. In fact, according to the European Journal of Human Genetics, Moroccans from northwestern Africa are genetically closer to Iberians and other South Europeans than to Middle Easterners or sub-Saharan Africans. ${ }^{9}$ LN has been described in various ethnic groups, including Caucasians, Asians, Latinos, and black Africans,${ }^{10}$ but little literature exists on $\mathrm{LN}$ features in North African patients, in particular 


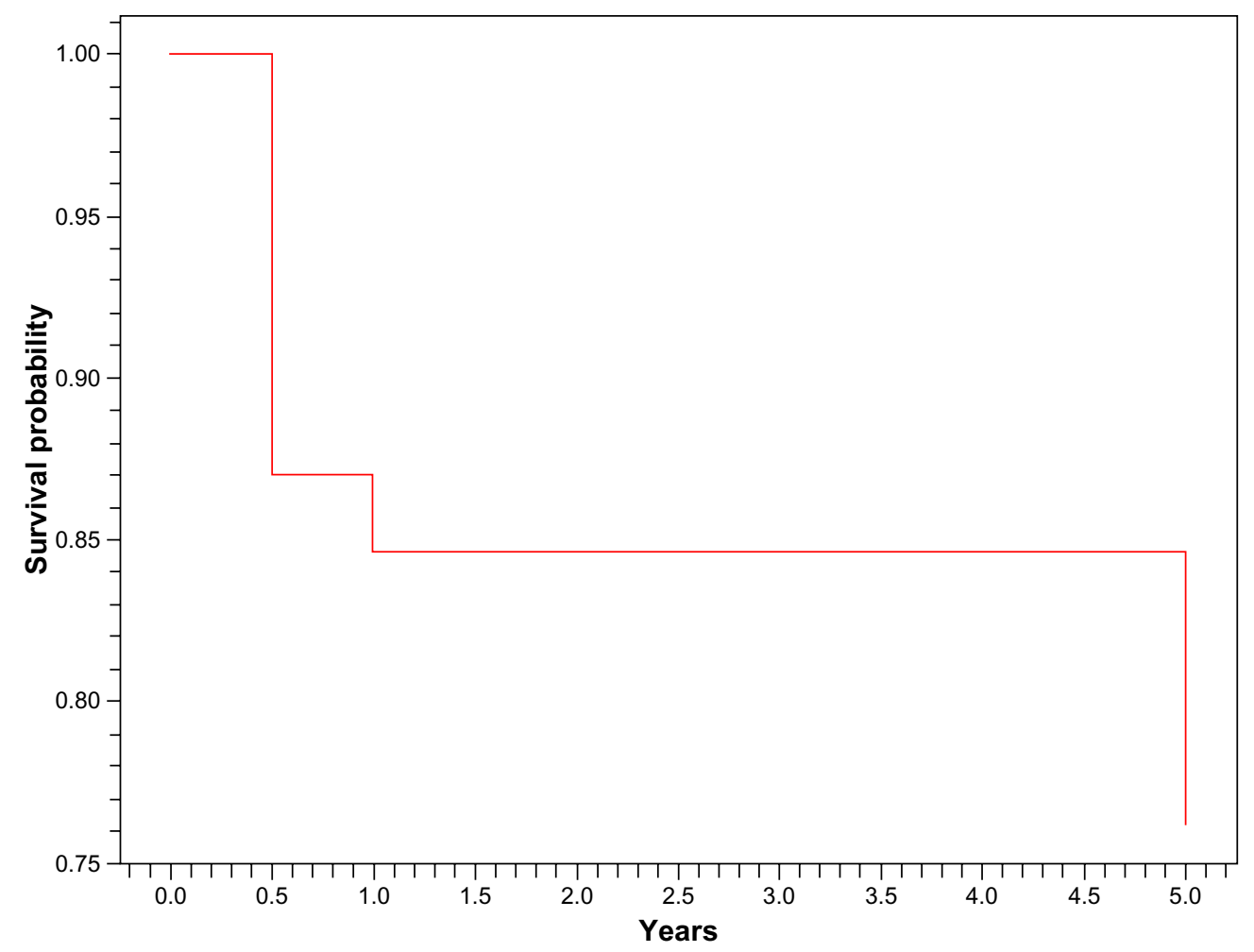

Figure 3 Kaplan-Meier global survival curve.

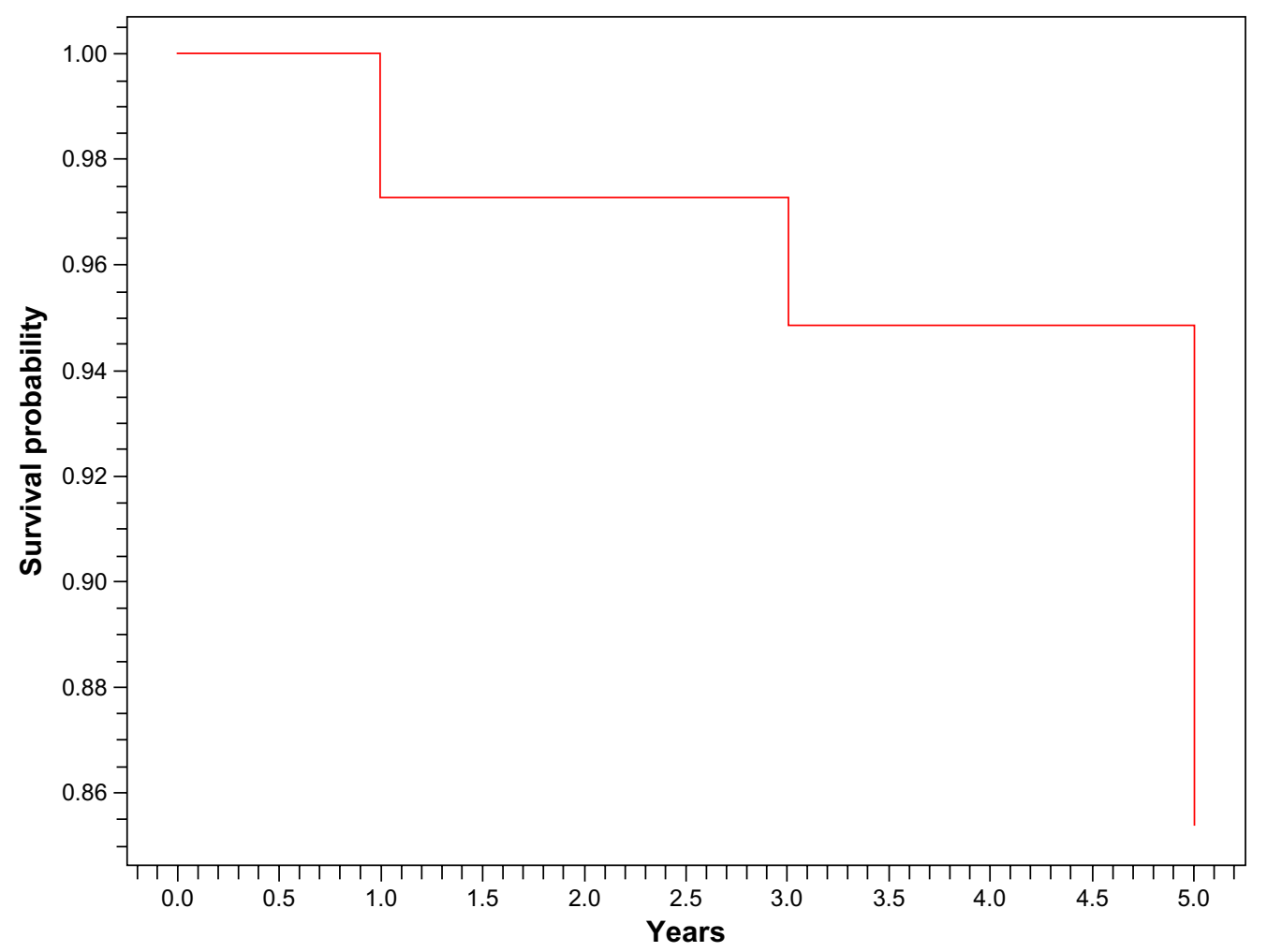

Figure 4 Kaplan-Meier survival curve without end-stage renal disease. 
Table 3 Prognostic power of patient characteristics at presentation to predict development of end-stage renal disease or death

\begin{tabular}{|c|c|c|c|}
\hline & \multicolumn{2}{|c|}{ Characteristics at presentation } & \multirow[t]{2}{*}{$P$-value } \\
\hline & $\begin{array}{l}\text { Patients alive with a } \\
\text { functioning kidney } \\
n=72(63.1 \%)\end{array}$ & $\begin{array}{l}\text { Patients in ESRD or } \\
\text { deceased } \\
n=42(36.8 \%)\end{array}$ & \\
\hline Age (years, mean $\pm S D$ ) & $29.48 \pm 8.89$ & $32.77 \pm 10.98$ & NS \\
\hline \multicolumn{4}{|l|}{ Sex } \\
\hline Male (\%) & 12.1 & 95.5 & NS \\
\hline Female (\%) & 87.9 & 4.5 & \\
\hline Months between SLE and LN diagnosis (mean \pm SD) & $10.4 \pm 3.5$ & $4.2 \pm 2.8$ & 0.04 \\
\hline Hypertension (\%) & 37.9 & 47.6 & NS \\
\hline Renal failure (\%) & 41.6 & 73.8 & 0.01 \\
\hline Serum creatinine < 15 mg/dL (\%) & 59.3 & 27.3 & NS \\
\hline Nephrotic syndrome (\%) & 51.7 & 59.1 & NS \\
\hline Hematuria (\%) & 58.3 & 66.6 & NS \\
\hline Leucopenia (\%) & 23.6 & 28.5 & NS \\
\hline Anemia (\%) & 58.3 & 90.4 & 0.003 \\
\hline Thrombocytopenia (\%) & 16.6 & 23.8 & NS \\
\hline Low C3 (\%) & 66.6 & 71.4 & NS \\
\hline Low C4 (\%) & 65.2 & 71.4 & NS \\
\hline Positive anti-dsDNA antibodies (\%) & 66.6 & 71.4 & NS \\
\hline
\end{tabular}

Abbreviations: NS, not significant; SLE, systemic lupus erythematosus; LN, lupus nephritis; ESRD, end-stage renal disease; NS, not significant; dsDNA, double-stranded DNA; SD, standard deviation.

from Morocco. Our goal for this retrospective study was to examine LN features among a Moroccan population that is large and ethnically heterogeneous.

All patients met the American Rheumatism Association criteria for SLE classification. Systemic manifestations in this work did not differ from what was observed in other studies, with predominance of joint and skin manifestations in $85 \%$ and $74 \%$, respectively. Chrysochou et $\mathrm{al}^{11}$ reported a frequency of $80 \%$ and $62 \%$, respectively. Renal manifestations in this study were marked by a high frequency of renal failure, nephrotic syndrome, hematuria, and hypertension. Similar results were seen in most studies, ${ }^{11-14}$ especially in the Tunisian cohort of Beji et al ${ }^{13}$ (Table 4).

Time between diagnosis of SLE and onset of renal disease was 9.7 months. This interval is very short compared to the

Table 4 Initial renal manifestations in some of the literature of lupus nephritis

\begin{tabular}{llllll}
\hline & $\begin{array}{l}\text { Our } \\
\text { study }\end{array}$ & $\begin{array}{l}\text { Chrysochou } \\
\text { et al" }\end{array}$ & $\begin{array}{l}\text { Bono } \\
\text { et al }\left.\right|^{12}\end{array}$ & $\begin{array}{l}\text { Beji } \\
\text { et al }{ }^{13}\end{array}$ & $\begin{array}{l}\text { Martins } \\
\text { et al }{ }^{14}\end{array}$ \\
\hline $\begin{array}{l}\text { Number } \\
\text { Renal failure (\%) }\end{array}$ & 114 & 50 & 110 & 211 & 78 \\
$\begin{array}{l}\text { Serum creatinine } \\
(\mathrm{mg} / \mathrm{dL})\end{array}$ & 2.36 & $\mathrm{II}$ & 77 & 51.6 & 39.7 \\
$\begin{array}{l}\text { Nephrotic } \\
\text { syndrome (\%) }\end{array}$ & 52.6 & 33 & - & - & 1.45 \\
$\begin{array}{l}\text { Hypertension (\%) } \\
\text { Hematuria (\%) }\end{array}$ & 33.3 & - & 45 & 47.7 & 16.7 \\
\hline
\end{tabular}

3 years observed in the study of Mok et al, ${ }^{15}$ between 3 and 4.4 years in the study of Brugos et al, ${ }^{16}$ and 4 years in the study of Chrysochou et al. ${ }^{11}$

Most studies with LN were performed according to the 1995 World Health Organization classification. In these studies, ${ }^{13,16-26}$ proliferative classes (particularly class IV) were predominant, occurring in up to $70 \%$ of patients. Our work was based on the 2003 International Society of Nephrology/ Renal Pathology Society classification of LN, but our findings are consistent with what was observed in previous studies. First, proliferative classes remain the most common form of LN. Second, we described a higher frequency of membranous glomerulonephritis similar to that published when combined classes are included, except in the Senegalese study, ${ }^{23}$ where class $\mathrm{V}$ was the most dominant form of $\mathrm{LN}$, observed in more than half of patients. Third, we noted $15.7 \%$ of biopsies not done. Brugos et $\mathrm{al}^{16}$ reported a similar result with a percentage of $17.9 \%$ (Table 5 ).

Combination CS and CYC administered either traditionally (monthly IV CYC) or in a modified regimen (smaller doses of CYC given at fortnightly intervals over a shortened treatment duration (Euro-lupus) can induce a complete or partial remission in more than $80 \%$ of patients with proliferative lupus nephritis (PLN). ${ }^{27} \mathrm{AZA}$ and MMF emerged recently as a good alternative to $\mathrm{CYC}$, especially as maintenance treatment. ${ }^{27}$ However, remission was recently reported to vary from $30 \%$ to $81 \%{ }^{28}$ Also, the incidence of LN flares varies in 
Table 5 Comparison of histological classes in various ethnic groups

\begin{tabular}{|c|c|c|c|c|c|c|c|c|}
\hline Population & $\begin{array}{l}\text { Number of } \\
\text { Biopsies }\end{array}$ & & & & & & & Combined \\
\hline Histological classes & & I & II & III & IV & $\mathbf{V}$ & VI & \\
\hline \multicolumn{9}{|l|}{ North Africans } \\
\hline Our study & $96^{a}$ & 3.1 & 2 & 10.4 & 62.5 & 8.3 & 3.1 & 10.4 \\
\hline Tunisia ${ }^{12}$ & $211^{\mathrm{b}}$ & 4.7 & 4.7 & 28.2 & 45.9 & 15.2 & 1.2 & ND \\
\hline \multicolumn{9}{|l|}{ Arabs of Middle-East } \\
\hline Saudi Arabia ${ }^{16}$ & $34^{b}$ & 0 & 11.7 & 8.8 & 55.9 & 23.5 & 0 & ND \\
\hline Kuwait $^{17}$ & $35^{\mathrm{b}}$ & 0 & 6 & 54 & 40 & 0 & 0 & ND \\
\hline $\mathrm{UAE}^{18}$ & $1 I^{b}$ & 0 & 27 & 36 & 27 & 9 & 0 & ND \\
\hline Egypt $^{19}$ & $148^{b}$ & 7.4 & 10.8 & 37.8 & 20.9 & 19.6 & 3.4 & ND \\
\hline Lebanon ${ }^{20}$ & $50^{\mathrm{b}}$ & 3.6 & 14.3 & 11.2 & 19.4 & 1.2 & 2.4 & ND \\
\hline \multicolumn{9}{|l|}{ White European } \\
\hline Hungary ${ }^{15}$ & $93^{\mathrm{b}}$ & 2.1 & 9.6 & 19.3 & 46.2 & 18.2 & 4.3 & ND \\
\hline \multicolumn{9}{|l|}{ Black } \\
\hline Jamaica $^{21}$ & $66^{\mathrm{b}}$ & 0 & 23 & 6 & 48 & 9 & 5 & ND \\
\hline Senegal 22 & $22^{\mathrm{b}}$ & 0 & 4.5 & 9 & 14.4 & 54.5 & 0 & ND \\
\hline Indo-Asian ${ }^{23}$ & $435^{b}$ & 10 & 18 & 7 & 58 & 12 & 0 & ND \\
\hline \multicolumn{9}{|l|}{ Oriental } \\
\hline Singapore ${ }^{24}$ & $42^{\mathrm{b}}$ & 14 & 7 & 19 & 36 & 24 & 0 & ND \\
\hline China $^{25}$ & $183^{b}$ & 1 & 5 & 25 & 55 & 14 & 0 & ND \\
\hline
\end{tabular}

Notes: anternational Society of Nephrology/Renal Pathology Society classification; ${ }^{b} \mathrm{WHO}$ classification. Abbreviations: ND, no data; UAE, United Arab Emirates; WHO, World Health Organization.

different studies between $27 \%$ and $66 \%{ }^{8}$ The discrepancies obtained from various studies can be attributed easily to (1) a difference in definitions, (2) racial and environmental differences between the groups of patients studied, and (3) disparities on treatment regimens. In our study, most patients with PLN had IV CYC administered monthly as induction and trimonthly as maintenance treatment because of efficacy and low cost. Remission occurred in less than half of cases, $60 \%$ of them relapsed at least once, $21 \%$ of patients progressed to ESRD, and $16 \%$ died. Similar results were reported by Beji et al: ${ }^{13}$ of the $211 \mathrm{LN}$ cases followed up for 103 months, remission was obtained in $55.3 \%$, relapses occurred in $51 \%$ of cases, $14.7 \%$ progressed to ESRD, and death was noted in $16.63 \%$.

In our study, it appears clear that $\mathrm{LN}$ in our population was particularly severe, compared with other published data. ${ }^{29} \mathrm{~A}$ number of factors may account for such a poor prognosis. Most lupus nephritis patients presented at our nephrology unit with severe clinical and biological features. At admission, 38 (33.3\%) patients had hypertension. Hematuria was seen in $87(76.3 \%)$ patients. Nephrotic syndrome was found in 60 patients $(52.6 \%)$ and renal failure in 68 patients $(59.6 \%)$. Seventeen $(14.9 \%)$ required acute renal replacement therapy. Furthermore, renal biopsy at admission showed mostly proliferative lupus classes: $10.4 \%$ class III, $62.5 \%$ class IV, and $10.4 \%$ of patients had combined classes (III + V and IV + V).
The severity of this disease in our patients cannot be related to race or ethnicity, since it has been recently established that Moroccans are genetically closer to Iberians and other Southern Europeans than to Middle Easterners or sub-Saharan Africans. ${ }^{9}$ Besides, LN in Southern Europeans is less severe than that found in our series. ${ }^{29}$

In fact, low remissions and high relapses in our context are mainly due to irregular follow-up, not allowing for correct surveillance in most cases. The low economic background of $57 \%$ of our patients probably plays a determining role in this condition, as most patients came from regions of the country in which there are no nephrologists in the local hospitals. Thus, they were referred to our university hospital for specialized care. In many cases, poverty and distance discourage patients from attending their consultation appointments. Eighty percent of patients were lost to view at 5 years, reflecting the short follow-up period, which was a major limitation in our study. The economic and socioeconomic background as well as the poor level of education encountered in most LN patients in our series might affect patients' adherence to treatment, though this issue wasn't evaluated in this study. Nonetheless, low compliance with prescribed treatments is highly suspected by medical staff and seldom admitted by patients. Therefore, the use of CYC pulses is a way to improve therapeutic compliance.

On the other hand, the high rate of relapse in our series may be explained by the maintenance-treatment regimen, 
mostly based on trimonthly 2-year CYC pulses. The main cause of death in LN patients is overtreatment, which may lead to life-threatening morbidity principally represented by severe infection. ${ }^{29}$ In our study, death was mostly due to infectious complications.

In our opinion, improvement in LN outcome in our country cannot be achieved without a thorough improvement of our health system. Bringing health structures closer to patients and training more doctors, especially nephrologists, throughout the country would help in diagnosing lupus at an early stage and perhaps help in preventing the development of some of its most devastating complications, such as nephritis. Besides, the generalization of health insurance among the Moroccan population can also play an undeniable role in allowing treatment continuance, especially in lowincome patients. Furthermore, the use of MMF or AZA as a maintenance therapy should be used on a larger scale in our patients, since these drugs are currently recommended. ${ }^{30}$ Moreover, a longer maintenance-therapy period would also help in preventing relapses, although to date there is still no available adequate data regarding when maintenance treatment can be withdrawn. ${ }^{30}$

\section{Conclusion}

This study represents the first report concerning LN in Morocco. Symptoms, histological findings, and outcomes were similar to those of non-Caucasian series. Our results revealed severe $\mathrm{LN}$ with predominance of proliferative forms and severe renal manifestations with poor renal and overall survival.

\section{Disclosure}

The authors report no conflicts of interest in this work.

\section{References}

1. Cameron JS. Lupus nephritis. J Am Soc Nephrol. 1999;10:413-424.

2. Cervera R, Khamashta MA, Font J, et al. Morbidity and mortality in systemic lupus erythematosus during a 10-year period: a comparison of early and late manifestations in a cohort of 1000 patients. Medicine. 2003;82:299-308.

3. Flanc RS, Roberts MA, Strippoli GF, Chadban SJ, Kerr PG, Atkins RC. Treatment for lupus nephritis. Cochrane Database Syst Rev. 2004;1: CD002922.

4. Appel GB, Cohen DJ, Pirani CL, Meltzer JI, Estes D. Long-term follow-up of patients with lupus nephritis. A study based on the classification of the World Health Organization. Am J Med. 1987;83:877-885.

5. Mok CC. Prognostic factors in lupus nephritis. Lupus. 2005;14: 39-44.
6. Tan EM, Cohen AS, Fries JF, et al. The 1982 revised criteria for the classification of systemic lupus erythematosus. Arthritis Rheum. 1982;25:1271-1277.

7. Weening JJ, D'Agati VD, Schwartz MM, et al. The classification of glomerulonephritis in systemic lupus erythematosus revisited. J Am Soc Nephrol. 2004;15:241-250.

8. Boumpas DT, Balow JE. Outcome criteria for lupus nephritis trials: a critical overview. Lupus. 1998;7:622-629.

9. Bosch E, Calafell F, Perez-Lezaun A. Genetic structure of north-west Africa revealed by STR analysis. Eur J Hum Genet. 2000;8:360-366.

10. Tikly M, Navarra SV. Lupus in the developing world - is it any different? Best Pract Res Clin Rheumatol. 2008;22:643-655.

11. Chrysochou C, Randhawa H, Reeve R, et al. Determinants of renal functional outcome in lupus nephritis: a single centre retrospective study. QJM. 2008;101:313-316.

12. Bono L, Cameron JS, Hicks JA. The very long-term prognosis and complications of lupus nephritis and its treatment. QJM. 1999;92: 211-218.

13. Beji S, Kaaroud H, Moussa FB, et al. [Lupus nephritis: about 211 cases.] Néphropathie lupique: a propos de 211 cas. Rev Med Interne. 2005;26:8-12. French.

14. Martins L, Rocha G, Rodrigues A, et al. Lupus nephritis: a retrospective review of 78 cases from a single center. Clin Nephrol. 2005;57: 114-119.

15. Mok CC, Ying $\mathrm{KY}, \mathrm{Ng} \mathrm{WL}$, et al. Long-term outcome of diffuse proliferative lupus glomerulonephritis treated with cyclophosphamide. Am J Med. 2006;119(4):355.e25-e33.

16. Brugos B, Kiss E, Szodoray P, Szegedi G, Zeher M. Retrospective analysis of patients with lupus nephritis: data from a large clinical immunological center in Hungary. Scand J Immunol. 2006;64:433-437.

17. Qayyum A, Nagy AA. Immuno-histological changes in lupus nephritis in female patients: a four-year study. Saudi J Kidney Dis Transpl. 2008;19:658-663.

18. Al-Jarallah K, AlAwadi A, Siddiqui H, et al. Systemic lupus erythematosus in Kuwait - hospital based study. Lupus. 1998;7:434-438.

19. Al Atta HM, Al Ahmed YH, Chandani AU. Serological markers in Arabs with lupus nephritis. Lupus. 1998;7:198-201.

20. Barsoum RS, Francis MR. Spectrum of glomerulonephritis in Egypt. Saudi J Kidney Dis Transpl. 2000;11:421-429.

21. Uthman IW, Muffarij AA, Mudawar WA, Nasr FW, Masri AF. Lupus nephritis in Lebanon. Lupus. 2001;10:378-381.

22. Williams W, Sargeant LA, Smikle M, Smith R, Edwards H, Shah D The outcome of lupus nephritis in Jamaican patients. Am J Med Sci. 2007;334:426-430.

23. Niang A, Ka EF, Pouye A, et al. Lupus nephritis in Senegal: a study of 42 cases. Saudi J Kidney Dis Transpl. 2008;19:470-474.

24. Malaviya AN, Chandrasekaran AN, Kumar A, Shamar PN. Systematic lupus erythematosus in India. Lupus. 1997;6:690-700.

25. Feng PH, Boey ML. Systematic lupus erythematosus in Chinese: the Singapore experience. Clin Rheumatol. 1996;15:143-147.

26. Mok CC, Wong RW, Lau CS. Lupus nephritis in Southern Chinese patients: clinicopathologic findings and long-term outcome. Am J Kidney Dis. 1999;34:315-323.

27. Buhaescu I, Covic A, Deray G. Treatment of proliferative lupus nephritis - a critical approach. Semin Arthritis Rheum. 2007;36: 224-237. French.

28. Fakhouri F, Lesavre P. [Current treatments of lupus nephritis.] Traitements actuels des néphropathies lupiques. Rev Rhum. 2007;74:759-764. French.

29. Moroni G, Quaglini S, Gallelli B. The long-term outcome of 93 patients with proliferative lupus nephritis. Nephrol Dial Transplant. 2007;22: 2531-2539.

30. Hahn BH, McMahon MA, Wilkinson A. American College of Rheumatology Guidelines for Screening, Treatment, and Management of Lupus Nephritis. Arthritis Care Res (Hoboken). 2012;64:797-808. 


\section{Publish your work in this journal}

The International Journal of Nephrology and Renovascular Disease is an international, peer-reviewed open-access journal focusing on the pathophysiology of the kidney and vascular supply. Epidemiology, screening, diagnosis, and treatment interventions are covered as well as basic science, biochemical and immunological studies. The journal welcomes

original research, clinical studies, reviews \& evaluations, expert opinion and commentary, case reports and extended reports. The manuscript management system is completely online and includes a very quick and fair peerreview system, which is all easy to use. Visit http://www.dovepress.com/ testimonials.php to read real quotes from published authors.

Submit your manuscript here: http://www.dovepress.com/international-journal-of-nephrology-and-renovascular-disease-journal 